Journal of Applied Pharmaceutical Science Vol. 7 (07), pp. 051-054, July, 2017

Available online at http://www.japsonline.com

DOI: 10.7324/JAPS.2017.70709

ISSN 2231-3354 (cc) EY-NC-SA

\title{
Pentacyclic triterpenes from leaves of Cagaita (Eugenia dysenterica)
}

\author{
Cristian A. Gasca ${ }^{1 *}$, Matheus Chaves ${ }^{1}$, Christopher W. Fagg $^{2}$, Pérola de Oliveira e Magalhães ${ }^{1}$, \\ Yris M. Fonseca-Bazzo ${ }^{1}$, Dâmaris Silveira ${ }^{1}$ \\ ${ }^{1}$ Department of Pharmacy, Faculty of Health Science, Darcy Ribeiro Universitary Campus, University of Brasilia, CEP 70910-900, Brasília DF. Brazil. \\ ${ }^{2}$ Department of Pharmacy, Campus Ceilândia, University of Brasilia, CEP: 72220-275, Brasília, Brazil.
}

\author{
ARTICLE INFO \\ Article history: \\ Received on: 01/09/2016 \\ Accepted on: 23/04/2017 \\ Available online: $30 / 07 / 2017$ \\ Key words: \\ Eugenia dysenterica, \\ Myrtaceae, triterpenes, mass \\ spectrometry.
}

\begin{abstract}
Phytochemical study of the leaves of Eugenia dysenterica led to the identification of five pentacyclic

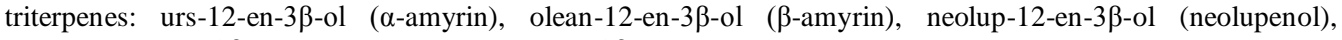

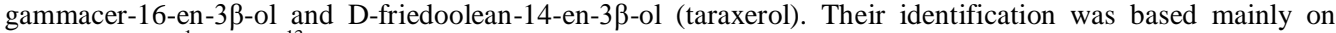
mass spectra, ${ }^{1} \mathrm{H}$ and ${ }^{13} \mathrm{C}$ NMR. Pentacyclic triterpenes have not been reported before in the literature as constituents of E. dysenterica.
\end{abstract}

\section{INTRODUCTION}

Brazil possesses one the richest biodiversity in the world, and Cerrado (Brazilian savannah), one the largest Brazilian biome, presents over 12.000 plant species (Silva et al., 2016), and more than $40 \%$ are native. Such characteristics make Cerrado one the most biodiverse savannah (Medeiros et al., 2015). The Myrtaceae is one of the most common family in Cerrado presenting, approximately, 14 genera and 210 species (Conceição and Aragão, 2010). The genus Eugenia comprises about 500 species (Cole et al., 2007), from those 379 are native to Brazil, and more than 80 can be found in Cerrado (REFLORA, 2016). One of them is Eugenia dysenterica (Mart.) DC, known as "cagaita" or "cagaiteira." Cerrado inhabitants eat the $E$. dysenterica fruits, which also are used by local food industry to prepare ice cream, desserts, jelly and others. A nutritional analysis showed that fruit pulp is rich in vitamins, folates, carotenoids (Cardoso et al., 2011), esters and other compounds (Silva et al., 2015).

* Corresponding Author

Email: cristiangasca25@gmail.com
Moreover, this species is widely used for several ethnomedicinal purposes, such as in the treatment of skin and bladder infection (Lima et al., 2011), for the treatment of diarrhea, cardiac diseases, diabetes, jaundice, and the reduction of blood cholesterol levels (Lima et al., 2010; Lima et al., 2011; Silva et al., 2015). Chemical characterization of aqueous, ethanol and methanol extracts from the leaves led to the identification of flavonoids, polyphenols (Prado et al., 2014) and sesquiterpenes (Costa et al., 2000; Duarte et al., 2010; Vilela et al., 2012). However, there is a lack of information about the less polar compounds from this plant species. Therefore, the aim of this work was to carry a phytochemical analysis on the hexane extract from E. dysenterica leaves.

\section{MATERIAL AND METHODS}

\section{General}

Thin-layer chromatography (TLC) analysis was carried out using aluminum-backed silica gel (60F254) plates (SigmaAldrich, L $\times$ W $20 \mathrm{~cm} \times 20 \mathrm{~cm}$ ). n-Hexane and ethyl acetate mixture was used as eluent, and the chromatograms were revealed by anisaldehyde- sulphuric acid reagent $(5 \%)$. 
GC-MS analysis was performed on a Shimadzu gas chromatograph mass spectrometer model QP2010. Compounds were separated on a Rtx-5MS capillary column (30 m x $0.25 \mathrm{~mm}$ x $0.25 \mu \mathrm{m}$ - Restek). Column temperature was programmed from 100 at $320{ }^{\circ} \mathrm{C}$, ranging $5{ }^{\circ} \mathrm{C} / \mathrm{min}$ with injector temperature at 250 ${ }^{\circ} \mathrm{C}$ and GC-MS interface at $280{ }^{\circ} \mathrm{C}$. Mass detector conditions were: electronic impact (EI) mode at $70 \mathrm{eV}$; source temperature: $280{ }^{\circ} \mathrm{C}$; scanning rate $0.5 \mathrm{scan} / \mathrm{s}$; mass acquisition range: $40-600$. Carrier gas was helium at $0.6 \mathrm{~mL} / \mathrm{min}$. The obtained mass spectra were compared to NIST standard reference database.

NMR spectroscopic data were recorded on Bruker AscendTM $600 \mathrm{MHz}$ spectrometer with $\mathrm{CDCl}_{3}$ as solvent and TMS as internal standard. Chemical shift values were reported in $\operatorname{ppm}(\delta)$.

\section{Plant material}

Leaves of Eugenia dysenterica were collected in June of 2014 at University of Brasilia campus, Brasilia DF (Brazil) and air-dried at room temperature $\left(30-35^{\circ} \mathrm{C}\right)$ for ten days. A voucher specimen (UB 914) was deposited in the University of Brasilia Herbarium (UB).

The dried and powdered leaves $(1 \mathrm{Kg})$ were extracted by maceration using hexane as solvent in the ratio 1:6 (sample:solvent, w/v). After filtration, the solvent was eliminated under reduce pressure (Hei- VAP advantage HB/HL/G1, Heidolph, Germany), giving hexane extract (HE, yield $2.2 \%$ ).

\section{Isolation procedure}

A preliminary fractionation of $\mathrm{HE}$ was carried out as previously described (Borges et al., 2016). Briefly, a $16.0 \mathrm{~g}$ aliquot of $\mathrm{HE}$ was submitted to silica gel $60 \mathrm{G}$ Merck filtration (silica layer: high $4.0 \mathrm{~cm}$, diameter $9.7 \mathrm{~cm})$, furnishing five fractions: Fhx (4.1 g); Fhx/AcOEt (11.0 g), FAcOEt (0.6 g), FAcOEt/MeOH (0.1 $\mathrm{g})$; and $\mathrm{FMeOH}(0.4 \mathrm{~g})$.

A $9.0 \mathrm{~g}$ aliquot of the fraction Fhx/AcOEt was chromatographed over silica gel (70-230 $\mu \mathrm{m}$, Merck) column (diameter: $2.5 \mathrm{~cm}$; high: $90.0 \mathrm{~cm}$ ), using a gradient of hexane and ethyl acetate as eluent. One hundred subfractions were collected and grouped based on their similar TLC pattern. Subfractions EDD $(\mathrm{Hx} / \mathrm{AcOEt}$ 9:1, $0.38 \mathrm{~g})$, EDE (Hx/AcOEt 9:1, $0.49 \mathrm{~g})$, EDF (Hx/AcOEt 8:2, $0.44 \mathrm{~g}$ ), and EDG (Hx/AcOEt 8:2, $0.40 \mathrm{~g}$ ), were submitted to spectrometric analysis.

\section{RESULTS AND DISCUSSION}

Five pentacyclic triterpenes were identified in the hexane extract of $E$. dysenterica: urs-12-en-3 $\beta$-ol ( $\alpha$-amyrin, 1$)$, olean-12en-3 $\beta$-ol ( $\beta$-amyrin, 2 ), neolup-12-en-3 $\beta$-ol (neolupenol, 3), Dfriedolean-14-en-3 $\beta$-ol (taraxerol, 4) and gammacer-16-en-3 $\beta$-ol (5). The obtained compounds were characterized by $\mathrm{MS},{ }^{1} \mathrm{H}$ and ${ }^{13} \mathrm{C}$ NMR spectra, by comparison with literature data (Mahato and Kundu, 1994; Sagar et al., 2004; Shiojima et al., 1992; Shiojima et al., 1989; Swain et al., 2010). Compounds 1-5 were identified (Figure 1) and assigned with the molecular formula $\mathrm{C}_{30} \mathrm{H}_{50} \mathrm{O}$. The compounds revealed positive respond when sprayed with methanolic - sulphuric acid reagent (5\%). Compounds 1 and 2 were identified as a mixture in the subfraction EDD with retention time of 51.58 and $51.19 \mathrm{~min}$, respectively. The mass spectrum at EI ionization mode showed a molecular peak at m/z 426.00 and a base peak at $\mathrm{m} / \mathrm{z} 218.10$. Spectrometric data are shown below:

$\alpha$-amyrin, $1 .{ }^{1} \mathrm{H}-\mathrm{NMR}\left(\mathrm{CDCl}_{3}, 600 \mathrm{MHz}\right): \delta 5.10(\mathrm{t}$, $\mathrm{J}=3.4 \mathrm{~Hz}, \mathrm{H}-12), 0.92$ (s, H-23), 0.74 (s, H-24), 0.73 (s, H-25), 0.89 (s, H-26), 1.04 (s, H-27), 0.95 (s, H-28), 0.85 (d, J=5.8, H29), 0.76 (d, J=6.9, H-30); ${ }^{13} \mathrm{C}-\mathrm{NMR}\left(\mathrm{CDCl}_{3}, 150 \mathrm{MHz}\right)$ : Results showed in Table 1; MS (m/z): 426 (5.03), 411 (7.09), 393 (1.98), 218 (100.00), 207 (33.25), 203 (40.05), 189 (20.04), 175 (16.13), 135 (21.23). $\beta$-amyrin, $2 .{ }^{1} \mathrm{H}-\mathrm{NMR}\left(\mathrm{CDCl}_{3}, 600 \mathrm{MHz}\right): \delta 5.15(\mathrm{t}$, $\mathrm{J}=3.4 \mathrm{~Hz}, \mathrm{H}-12), 0.77$ (s, H-23), 0.90 (s, H-24), 0.73 (s, H-25), 0.94 (s, H-26), 1.10 (s, H-27), 1.06 (s, H-28), 0.87 (s, H-29), 0.80 (s, H-30); ${ }^{13} \mathrm{C}-\mathrm{NMR}\left(\mathrm{CDCl}_{3}, 150 \mathrm{MHz}\right)$ : Results are shown in Table 1; MS (m/z): 426 (5.44), 411 (0.62), 393 (2.38), 218 (100.00), 207 (22.82), 203 (30.01), 189 (33.92), 175 (11.61), 135 (39.64). The $\Delta^{12}$-double bond was identified by signals at $\delta 124.4$ and $139.3 \mathrm{ppm}$; and 121.7 and $145.2 \mathrm{ppm}$ in the ${ }^{13} \mathrm{C}-\mathrm{NMR}$ spectrum, assigned to C-12 and C-13, respectively, of urs-12-entype and olean-12-ene-type skeletons (Mahato and Kundu, 1994; Shiojima et al., 1992).
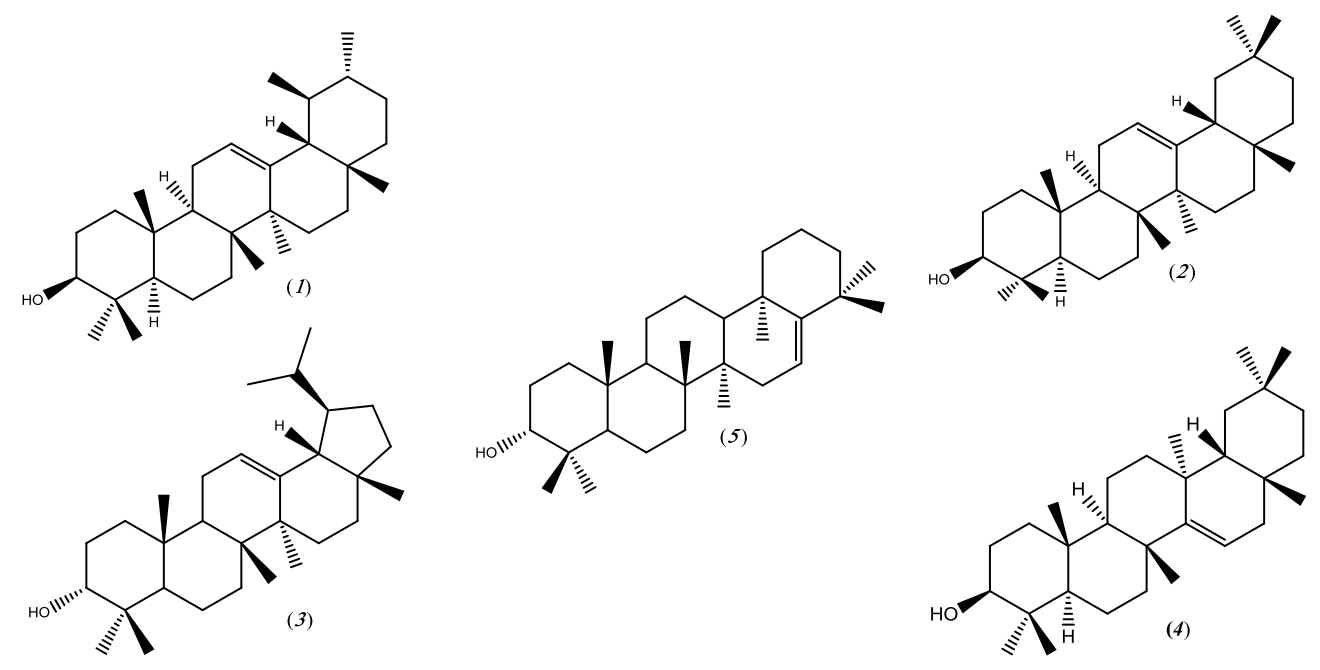

Fig. 1: Pentacyclic triterpenes identified in E. dysenterica. 
Compound 3 was identified in the subfraction EDE with retention time of $51.05 \mathrm{~min}$. The mass spectrum (EI-MS) showed a molecular peak at $\mathrm{m} / \mathrm{z} 426.00$ and a base peak at $\mathrm{m} / \mathrm{z} 218.15$. Neolupenol, 3: ${ }^{1} \mathrm{H}-\mathrm{NMR}\left(\mathrm{CDCl}_{3}, 600 \mathrm{MHz}\right): \delta 3.20(\mathrm{dd}, \mathrm{J}=9.8$ and 5.1, H-3), 5.15 (t, J=3.7 Hz, H-12), 1.06 (s, H-23), 0.79 (s, H-24), 0.94 (s, H-25), 0.99 (s, H-26), 1.22 (s, H-27), 0.91 (s, H-28), 0.76 (d, J=4.8, H-29), 0.85 (d, J=4.8, H-30); ${ }^{13} \mathrm{C}-\mathrm{NMR}\left(\mathrm{CDCl}_{3}, 150\right.$ MHz): Results are shown in Table 1; MS (m/z):426 (7.51), 411 (13.72), 393 (2.68), 218 (100.00), 207 (18.67), 203 (71.37), 189 (74.56), 175 (22.54), 135 (37.96). The presence of a $\Delta^{12}$-double bond was corroborated by signals at $\delta 124.4$ and 139.6 in the ${ }^{13} \mathrm{C}$ NMR spectrum, assigned to C-12 and C-13, respectively. Hence on the basis of its all spectral data $\mathbf{3}$ was characterized as Neolupenol (Sagar et al., 2004; Shiojima et al., 1992).

Compound 4 was identified in the subfraction EDF with retention time of $50.85 \mathrm{~min}$. The mass spectrum (EI-MS) showed a molecular peak at m/z 426.00 and a base peak at m/z 204.10.

Taraxerol, 4: ${ }^{1} \mathrm{H}-\mathrm{NMR}\left(\mathrm{CDCl}_{3}, 600 \mathrm{MHz}\right): \delta 3.19(\mathrm{~m}, \mathrm{H}-$ 3), 5.52 (dd, J=8.1 and $3.3 \mathrm{~Hz}, \mathrm{H}-15), 1.89$ (dd, H-16), 0.97 (s, H23), 0.90 (s, H-24), 0.79 (s, H-25), 0.89 (s, H-26), 1.10 (s, H-27), 0.80 (s, H-28), 0.92 (s, H-29), 0.89 (s, H-30); ${ }^{13} \mathrm{C}-\mathrm{NMR}\left(\mathrm{CDCl}_{3}\right.$, $150 \mathrm{MHz}$ ): Results are shown in Table 1; MS (m/z):426 (6.09), 411 (9.48), 302 (29.78), 287 (49.01), 271 (3.27), 269 (32.04), 257 (19.01), 207 (48.56), 204 (100.00), 189 (91.54), 135 (90.41) e 123 (33.90). The presence of a $\Delta^{14}$-double bond was corroborated by signals at $\delta 158.1$ and 116.9 in the ${ }^{13} \mathrm{C}-\mathrm{NMR}$ spectrum, assigned to $\mathrm{C}-14$ and $\mathrm{C}-15$. Thus the compound 4 was identified as taraxerol (Shiojima et al., 1992; Swain et al., 2010).
Compound 5 was identified in the subfraction EDG with retention time of 51.17 minutes. The mass spectrum (EI-MS) showed a molecular peak at $\mathrm{m} / \mathrm{z} 426.00$ and a base peak at $\mathrm{m} / \mathrm{z}$ 189.10. Gammacer-16-en-3 $\beta$-ol, 5: ${ }^{1} \mathrm{H}-\mathrm{NMR}\left(\mathrm{CDCl}_{3}, 600 \mathrm{MHz}\right): \delta$ $3.20(\mathrm{dd}, \mathrm{J}=5.3$ and $11.1 \mathrm{~Hz}, \mathrm{H}-3), 5.49(\mathrm{dd}, \mathrm{J}=3.0$ and $5.1 \mathrm{~Hz}, \mathrm{H}-$ 16), 0.99 (s, H-23), 0.77 (s, H-24), 0.84 (s, H-25), 0.94 (s, H-26), 0.98 (s, H-27), 1.04 (s, H-28), 1.06 (s, H-29), 1.10 (s, H-30); ${ }^{13} \mathrm{C}-$ NMR $\left(\mathrm{CDCl}_{3}, 150 \mathrm{MHz}\right)$ : Results are shown in Table 1; MS (m/z):426 (510.54), 411 (25.08), 393 (3.95), 218 (28.47), 204 (75.79), 203 (24.69), 189 (100.00), 177 (77.28), 150 (16.18), 135 (41.21). The presence of a $\Delta^{16}$-double bond was corroborated by signals at $\delta 116.9$ and 145.2 in the ${ }^{13} \mathrm{C}$-NMR spectrum, assigned to C-16 and C-17, respectively, of gammacer-16-en-type skeletons (Shiojima et al., 1992; Shiojima et al., 1989).

Plant extracts containing pentacyclic triterpenes and their isolated compounds had been studied for their strong cytotoxic properties. Previously results suggested this kind of metabolites as potentially cytotoxic toward in neoplastic cells with promising results in the treatment of melanoma, glioma, laryngeal cancer, ovarian carcinoma, colon adenocarcinoma, pancreatic carcinoma, cervical carcinoma, epithelial carcinoma, prostate cancer, , hepatic cancer, breast cancer, colorectal cancer, colon cancer, gastric cancer, lung cancer, leukemia and neuroma (Chudzik et al., 2015; Drag et al., 2009; Gnoatto et al., 2008; Kaweetripob et al., 2013; Vazquez et al., 2012).

Additional studies can be conducted with the hexane extract of $E$ dysenterica as a promising source of pentacyclic triterpenes of natural origin.

Table 1: NMR ${ }^{13} \mathrm{C}$ dates from the pentacyclic triterpenes compared with literature data.

\begin{tabular}{|c|c|c|c|c|c|c|c|c|c|}
\hline \multirow{3}{*}{$\mathbf{C}$} & \multirow{3}{*}{ EDD } & \multirow{2}{*}{\multicolumn{2}{|c|}{$\frac{\text { Mahato and Kundu (1994) }}{{ }^{13} \mathrm{C}(\delta)}$}} & \multirow{3}{*}{ EDE } & \multirow{3}{*}{$\begin{array}{c}\text { Sagar et al. (2004) } \\
{ }^{13} \mathrm{C}(\delta) \\
(3)\end{array}$} & \multirow{3}{*}{ EDF } & \multirow{3}{*}{$\begin{array}{c}\text { Swain et al. (2010) } \\
{ }^{13} \mathrm{C}(\delta) \\
(4)\end{array}$} & \multirow{3}{*}{ EDG } & \multirow{3}{*}{$\begin{array}{c}\text { Shiojima et al. (1989) } \\
{ }^{13} \mathrm{C}(\delta) \\
(5)\end{array}$} \\
\hline & & & & & & & & & \\
\hline & & (1) & (2) & & & & & & \\
\hline 1 & 38.6 & 38.7 & 38.7 & 41.7 & 41.9 & 38.1 & 38.0 & 38.8 & 38.7 \\
\hline 2 & $27.2 ; 27.3$ & 27.2 & 27.3 & 28.4 & 28.5 & 27.2 & 27.1 & 27.4 & 27.4 \\
\hline 3 & $79.0 ; 79.1$ & 78.3 & 79.0 & 79.1 & 79.5 & 79.0 & 79.1 & 79.1 & 79.1 \\
\hline 4 & $38.6 ; 38.8$ & 38.7 & 38.8 & 37.2 & 37.3 & 38.6 & 38.8 & 38.9 & 38.9 \\
\hline 5 & $55.2 ; 55.3$ & 55.2 & 55.3 & 55.5 & 55.6 & 55.5 & 55.5 & 55.2 & 55.3 \\
\hline 6 & $18.3 ; 18.4$ & 18.3 & 18.5 & 19.0 & 18.8 & 18.4 & 18.8 & 18.4 & 18.7 \\
\hline 7 & $32.7 ; 32.8$ & 32.9 & 32.8 & 33.4 & 33.4 & 35.1 & 35.1 & 33.4 & 33.5 \\
\hline 8 & $40.1 ; 38.8$ & 40.0 & 38.8 & 40.1 & 40.4 & 39.0 & 39.0 & 41.3 & 41.3 \\
\hline 9 & 47.7 & 47.7 & 47.7 & 48.0 & 48.1 & 48.8 & 48.7 & 49.3 & 50.5 \\
\hline 10 & $36.9 ; 37.6$ & 36.9 & 37.6 & 34.3 & 34.1 & 37.8 & 37.7 & 37.2 & 37.1 \\
\hline 11 & $23.4 ; 23.5$ & 23.3 & 23.6 & 27.3 & 27.0 & 17.5 & 17.5 & 21.4 & 21.4 \\
\hline 12 & $124.4 ; 121.7$ & 124.3 & 121.8 & 124.4 & 124.8 & 35.8 & 35.8 & 22.7 & 22.7 \\
\hline 13 & $139.6 ; 145.2$ & 139.3 & 145.1 & 139.6 & 140.0 & 37.7 & 37.7 & 46.8 & 46.5 \\
\hline 14 & $42.1 ; 41.6$ & 42.0 & 41.8 & 42.1 & 42.5 & 158.1 & 158.1 & 39.6 & 39.4 \\
\hline 15 & $28.8 ; 26.2$ & 28.7 & 26.2 & 23.7 & 23.8 & 116.9 & 116.9 & 33.3 & 33.4 \\
\hline 16 & $26.6 ; 27.0$ & 26.6 & 27.0 & 27.9 & 27.7 & 36.7 & 36.7 & 116.9 & 117.8 \\
\hline 17 & $33.7 ; 32.5$ & 33.7 & 32.5 & 39.6 & 39.2 & 37.6 & 37.6 & 145.2 & 147.7 \\
\hline 18 & $59.1 ; 47.2$ & 58.9 & 47.4 & 59.1 & 59.5 & 49.3 & 49.3 & 37.7 & 37.7 \\
\hline 19 & $39.7 ; 46.9$ & 39.6 & 46.9 & 40.0 & 40.1 & 41.3 & 41.3 & 41.6 & 41.5 \\
\hline 20 & $39.7 ; 31.1$ & 39.6 & 31.1 & 39.9 & 40.0 & 28.8 & 28.8 & 18.3 & 18.2 \\
\hline 21 & $31.3 ; 34.8$ & 31.2 & 34.8 & 31.9 & 31.7 & 33.8 & 33.7 & 41.7 & 41.8 \\
\hline 22 & $41.5 ; 37.2$ & 41.5 & 37.2 & 39.6 & 39.2 & 33.1 & 33.1 & 36.7 & 36.1 \\
\hline 23 & $28.1 ; 28.2$ & 28.1 & 28.2 & 28.4 & 28.5 & 28.0 & 28.0 & 28.1 & 28.1 \\
\hline 24 & $15.6 ; 15.4$ & 15.6 & 15.5 & 16.1 & 16.1 & 15.4 & 15.4 & 15.5 & 15.5 \\
\hline 25 & $15.5 ; 16.7$ & 15.6 & 16.6 & 16.0 & 16.0 & 15.5 & 15.4 & 16.1 & 16.2 \\
\hline 26 & $16.8 ; 16.9$ & 16.8 & 16.9 & 18.0 & 17.9 & 29.9 & 29.9 & 16.9 & 16.9 \\
\hline 27 & $23.3 ; 26.0$ & 23.3 & 26.0 & 29.2 & 29.1 & 25.9 & 25.9 & 17.5 & 17.6 \\
\hline 28 & $28.0 ; 28.4$ & 28.1 & 28.4 & 23.7 & 23.7 & 29.7 & 29.8 & 29.9 & 29.9 \\
\hline 29 & $17.5 ; 33.3$ & 17.4 & 33.3 & 21.4 & 21.8 & 33.4 & 33.3 & 20.9 & 20.6 \\
\hline 30 & $21.1 ; 23.7$ & 21.3 & 23.7 & 17.5 & 17.3 & 21.3 & 21.3 & 33.4 & 33.5 \\
\hline
\end{tabular}




\section{CONCLUSION}

Five pentacyclic triterpenes were identified in the hexane extract of $E$ dysenterica, $\alpha$-amyrin, $\beta$-amyrin, neolupenol, gammacer-16-en-3 $\beta$-ol, and taraxerol. The compounds from $E$. dysenterica are widespread in higher plants, and present several confirmed biological activities. However, as far we know, it is the first report about triterpenes from hexane extract of $E$. dysenterica leaves.

\section{ACKNOWLEDGMENTS}

The authors are grateful to the Coordination for the Improvement of Higher Education Personnel (CAPES), the National Council for Scientific and Technological Development CNPq, Foundation for Research Support of the Federal District FAP-DF, and the Dean of Research and Graduate Studies of the University of Brasilia.

Conflict of Interests: There are no conflicts of interest.

\section{REFERENCES}

Borges G, Ferreira J, Elias S, Guerra E, Silveira D, Simeoni LA. Cytotoxic effect of Plectranthus neochilus extracts in head and neck carcinoma cell lines. African J Pharm Pharmacol, 2016; 10 (10): 157-163.

Cardoso L, Martino HS, Moreira AV, Ribeiro S, Pinheiro HM. Cagaita (Eugenia dysenterica DC.) of the Cerrado of Minas Gerais, Brazil: Physical and chemical characterization, carotenoids and vitamins. Food Res Int, 2011; 44 (7): 2151-2154.

Chudzik M, Korzonek-Szlacheta I, Król W. Triterpenes as potentially cytotoxic compounds. Molecules, 2015; 20 (1): 1610-1625.

Cole R, Haber W, Setzer W. Chemical composition of essential oils of seven species of Eugenia from Monteverde, Costa Rica. Biochem Syst Ecol, 2007; 35 (12): 877-886.

Conceição G, Aragão J. Diversidade e importância econômica das Myrtaceae do cerrado, Parque Estadual do Mirador, Maranhão. Scientia Plena, 2010; 6 (7): 1-9.

Costa TR, Fernandes OFL, Santos SC, Oliveira Cl, Lião LM, Ferri PH, Paula JR, Ferreira HD, Sales BHN, Silva MRR. Antifungal activity of volatile constituents of Eugenia dysenterica leaf oil. J Ethnopharmacol, 2000; 72 (1): 111-117.

Drag M, Surowiak P, Drag-Zalesinska M, Dietel M, Lage H, Oleksyszyn J. Comparision of the cytotoxic effects of birch bark extract, betulin and betulinic acid towards human gastric carcinoma and pancreatic carcinoma drug-sensitive and drug-resistant cell lines. Molecules, 2009; 14 (4): 1639-1651.

Duarte AR, Naves RR, Santos SC, Seraphin JC, Ferri PH. Genetic and environmental influence on essential oil composition of Eugenia dysenterica. J Braz Chem Soc, 2010; 21 (8): 1459-1467.

Gnoatto SC, Dassonville-Klimpt A, Da Nascimento S, Galéra P, Boumediene K, Gosmann G, Sonnet P, Moslemi S. Evaluation of ursolic acid isolated from Ilex paraguariensis and derivatives on aromatase inhibition. Eur J Med Chem, 2008; 43 (9): 1865-1877.

Kaweetripob W, Mahidol C, Prawat H, Ruchirawat S. Lupane, friedelane, oleanane, and ursane triterpenes from the stem of Siphonodon celastrineus Griff. Phytochemistry, 2013; 96: 404-417.

Lima T, Silva O, Oliveira J, Vasconcelos I, Scalabrin F, Rocha T, Grossi M, Silva L, Guadagnin R, Quirino B. Identification of $E$. dysenterica laxative peptide: A novel strategy in the treatment of chronic constipation and irritable bowel syndrome. Peptides, 2010; 31 (8): 1426 1433.
Lima T, Silva O, Silva L, Rocha T, Grossi M, Franco O, Leonardecz E. In vivo effects of Cagaita (Eugenia dysenterica, DC.) leaf extracts on diarrhea treatment. Evid Based Complement Alternat Med, 2011; 2011: 1-10.

Mahato S, Kundu A. ${ }^{13} \mathrm{C}$ NMR spectra of pentacyclic triterpenoids - a compilation and some salient features. Phytochemistry, 1994; 37 (6): 1517-1575

Medeiros F, Menezzi C, Bizzo H, Vieira R. Scents from Brazilian Cerrado: Psidium myrsinites DC.(Myrtaceae) leaves and inflorescences essential oil. J Essential Oil Res, 2015; 27 (4): 289-292.

Prado LC, Silva DB, Oliveira G, Hiraki KR, Canabrava HA, Bispo L. The gastroprotective effects of Eugenia dysenterica (Myrtaceae) leaf extract: The possible role of condensed tannins. Biol Pharm Bull, 2014; 37 (5): 722-730.

REFLORA, 2016. Eugenia, Flora do Brasil 2020 em construção. Jardim Botânico do Rio de Janeiro, Rio de Janeiro.

Sagar R, Dhoke ND, Shaw A. A convenient approach towards separation and identification of triterpenes of $\Delta 12$ lupane series. Indian $\mathrm{J}$ Chem, Sect B, 2004; 43 (11): 2446-2451.

Shiojima K, Arai Y, Masuda K, Takase Y, Ageta T, Ageta H. Mass spectra of pentacyclic triterpenoids. Chem Pharm Bull, 1992; 40 (7): 1683-1690.

Shiojima K, Masuda K, Lin T, Suzuki H, Ageta H, Inoue M, Ishida T. Composite constituents: Three gammacer-16-ene derivatives, novel triterpenoids isolated from roots of Picris hieracioides subsp. japonica. Tetrahedron Lett, 1989; 30 (37): 4977-4980.

Silva EP, Abreu WC, Goçalves OA, Damiani C, Vilas Boas EV. Characterization of chemical and mineral composition of marolo (Annona crassiflora Mart) during physiological development. Food Sci Technol (Campinas), 2016; 37 (1): 13-18.

Silva SM, Gasca CA, Fonseca YM, Magalhães PO, Silveira D. Eugenia dysenterica Mart. Ex DC. (Cagaita): Brazilian plant with therapeutic potential. Infarma, 2015; 27 (1): 49-95.

Swain S, Rout K, Chand P. Production of Triterpenoid Anticancer Compound Taraxerol in Agrobacterium-Transformed Root Cultures of Butterfly Pea (Clitoria ternatea L.). Appl Biochem Biotech, 2010; 12 (S1): 9791-9798.

Vazquez L, Palazon J, Navarro A. 2012. The Pentacyclic Triterpenes $\alpha, \beta$-amyrins: A Review of Sources and Biological Activities. In: Rao V., ed. Phytochemicals - A global perspective of their role in nutrition and health. In Tech 487-502.

Vilela EC, Carvalho TC, Duarte AR, Naves RR, Santos SC, Seraphin JC, Ferri PH. Spatial structure of Eugenia dysenterica based on essential oil chemovariations and implications for conservation and management of the genetic diversity of its populations. J Braz Chem Soc, 2012; 23 (10): 1776-1782.

How to cite this article:

Gasca CA, Chaves M, Fagg CW, Magalhães PO, Fonseca-Bazzo YM, Silveira D. Pentacyclic triterpenes from leaves of Cagaita (Eugenia dysenterica). J App Pharm Sci, 2017; 7 (07): 051-054. 